\title{
ELECTRIC CURRENT CHARACTERISTICS OF THE INJECTOR GENERATING FUEL DOSES
}

\author{
Krzysztof WIĘCŁAWSKI ${ }^{1}$, Jędrzej MĄCZAK ${ }^{2}$, Krzysztof SZCZUROWSKI ${ }^{3}$ \\ Institute of Vehicles, Warsaw University of Technology, Poland \\ 1'e-mail: krzysztof.wieclawski@pw.edu.pl; ${ }^{2}$ e-mail: jedrzej.maczak@pw.edu.pl; \\ e-mail: Krzysztof.szczurowski@pw.edu.pl
}

\begin{abstract}
In this article, the proposal for modelling the gas (fuel) injector based on observations of changes in the current during operation of the needle is presented. The aim of this work is indicating that the dosage characteristics can be mapped by means of the current characteristics. Moreover, observation of the current allows for determining the actual position of the needle. The time of the real fuel flow and the injector phase position can be determined with a microsecond resolution. The injector core inductance is a constant quantity but as a result of the needle movement and change in the permeability, inductance of the core varies depending on the needle position. These quantities, closely related to the current flowing through the coil, are described by means of differential equations resulting from the Kirchhoff's law, due to which changes taking place can be substantiated. Control of the flux enables the precise controlling of the injector in the actual time, thanks to the employment of fast analogue-digital converters and phase are taken into consideration.
\end{abstract}

Keywords: inductance, magnetic flux, injector

\section{CHARAKTERYSTYKA PRĄDOWA WTRYSKIWACZA GENERUJĄCEGO DAWKI PALIWOWE}

\section{Streszczenie}

W artykule zaprezentowano propozycję modelowania wtryskiwacza gazowego (paliwowego), na podstawie obserwacji zmian prądowych, w trakcie wykonywania pracy przez jego iglicę. Celem artykułu jest pokazanie, że można poprzez charakterystyki prądowe, odzwierciedlić charakterystyki dawkowania. Dodatkowo obserwacja prądu, pozwala określić aktualną pozycję iglicy. Możemy określić czas rzeczywistego przepływu paliwa i położenie fazowe wtrysku z precyzją mikrosekundową. Indukcyjność rdzenia wtryskiwacza jest wielkością stałą, ale w wyniku przesuwania iglicy i zmiany przenikalności, indukcyjność rdzenia zmienia się $\mathrm{w}$ zależności od położenia iglicy. Wielkości te, ściśle związane $\mathrm{z}$ przepływającym przez cewkę prądem, opisane są przez równania różniczkowe wynikające $\mathrm{z}$ prawa Kirchhoffa, dzięki czemu potrafimy uzasadnić zachodzące zmiany. Kontrola przepływu, pozwala na precyzyjne sterowanie wtryskiwaczem w czasie bieżącym, dzięki wykorzystaniu szybkich przetworników analogowo - cyfrowych i odpowiednich algorytmów. W sterowaniu uwzględniamy opóźnienia w działaniu impulsowego wtryskiwacza i przesunięcia fazy przepływu.

Słowa kluczowe: indukcyjność, strumień magnetyczny, wtryskiwacz

\section{INTRODUCTION}

The article presents the proposal for modelling the gas (fuel) injector based on observations of changes in the current during operation of the needle. The aim of this work is indicating that the dosage characteristics can be mapped by means of the current characteristics. Figure 1 illustrates the Hanna 2000 gas injector. The quantities measured include the mass of gas doses, gas injection pressure, temperature, injection time (duration), number of injections, current and voltage on the injector's coil. Due to the method of determining these quantities, observations can be extended onto the magnetic flux around the injector's coil. The subsequent task is determining whether observation of changes in the current during generation of fuel doses by the injector allows for diagnosing the actual position of the needle.

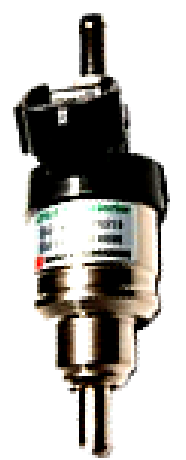

Fig. 1. Hanna 2000 gas injector 
Due to the method of determining these quantities, observations can be extended onto the magnetic flux around the injector's coil. The subsequent task is determining whether observation of changes in the current during generation of fuel doses by the injector allows for diagnosing the actual position of the needle [1]. Changes in the current in the coil of the operating injector are closely related to the current flowing through the coil are described by the differential equations resulting from the Kirchhoff's law (1). If we are able to determine the needle's position, we will know precisely when the needle is opened (lifted) and closed.

Can the injector be precisely controlled, using such information? This is a crucial question because the needle, due to delays in opening and closing the nozzle, causes change in injection time relative to the preset time, as well as the flow delay in the given phase. There exist many publications describing the flow through the injector. The tests were conducted at the laboratory test benches, determining the flow with the mass flow meter [2, 3, 4, 5]. Mathematical models [6, 7, 8, 9] were employed in analysis, using simulation programmes such as Matlab Simulink. Delays in opening and closing the gas injector have been discussed, based on the measurement of the increase in the pressure wave downstream of the injector, generated after its bias control [10, 11]. The US6657847 patent application is very interesting; it describes using measurement of the injector core inductance to describe changes taking place during its operation [12]. In the successive work, simulation research has been performed, focusing on evaluation of the fuel flow intensity; the selected, most popular gas injectors have been compared, and the results of the coils' parameters have been shown, as well as the time of reaction to the control pulse $[13,14,1]$. In work [15], delay times of the opening and closing the needle have been determined, by means of analyzing the vibration characteristics and current curves.

\section{LABORATORY STAND}

In order to perform the analysis of the gas injector work, a laboratory stand was built (Fig. 2), allowing for injection of the gas doses similar to the actual doses. This allows the automation of measurement (Data acquisition module, Fig. 3), an automatic recording of parameters and the possibility of the ongoing display of the preset parameters and those received from sensors, including information acquired from the WLC2 scales, as well as in expanding the data with the current and voltage records of the injector control (Control module, Fig. 4). Measurements were made regarding the $U_{c}$ controller voltage, the $U_{\text {inj }}$ injector voltage, and the intensity of the current supplying the injector $\mathrm{I}_{\mathrm{c}}$. Sampling of the acquired data related to the measured current values amounted to 51.2
$\mathrm{kHz}$. Due to the automation of the data acquisition process, and the automatic generation of plots within the LabVIEW environment, a wide range of results for all the individual injections was obtained, which is a huge statistical database where every individual injection is described with a set of parameters.

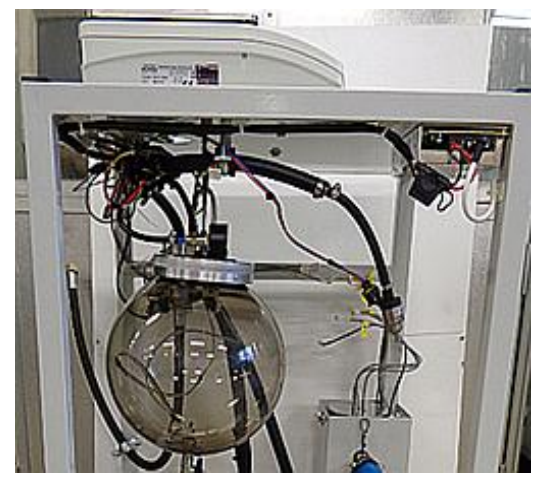

Fig. 2. Laboratory appliances during testing

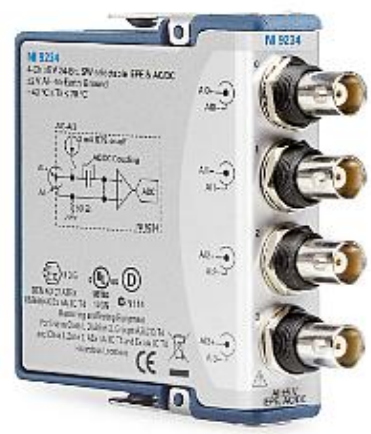

Fig. 3. Data acquisition module

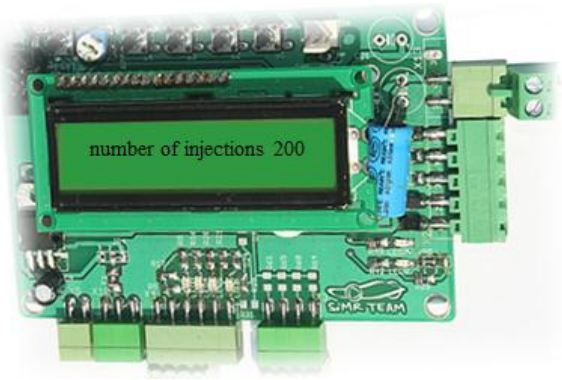

Fig. 4. Control module

\section{DESCRIPTION OF CHANGES IN CURRENT AND VOLTAGE IN THE INJECTOR COIL - THE KIRCHHOFF EQUATION}

Tests providing the foundation for this study were conducted using the gas injector. Each of the injector types, dosing petrol, gas or diesel, has a core consisting of the coil and the needle closing the nozzle; only the piezoelectric injector of the common rail system generates flow by means of change in the shape of the crystal stack. The gas injector consists of an injector casing with intake and outlet tips, an electrical attachment, solenoid 
coil, and plunger, which is a working element cutting off the fuel. The fuel intake is cut off with a plunger, pressed upon the valve seat. Pressing the valve element against the seat is accomplished by means of a spring and a difference in gas pressure before and after the valve. Opening the valve is performed with an electromagnetic coil, attracting the valve plunger during the current flow. The circuit of the injector coil can be considered as a circuit of electrical resistance $\mathrm{R}$, inductance $\mathrm{L}$ (with active electromotive force $\varepsilon$ ) in series. The Kirchhoff equation for this circuit:

$$
\varepsilon_{0}+\varepsilon_{S I}=R I
$$

where:

$\varepsilon_{0}$ - electromotive force of the source

$\varepsilon_{S I}$ - electromotive force self-induction

$R$ - resistance

$I$ - electric current

$\varphi$ - magnetic flux

$$
\varepsilon_{S I}=-\frac{d \varphi}{d t}
$$

$L$ - magnetic circuit inductance

$t$ - time

$$
\begin{gathered}
\varphi=L I \\
\varepsilon_{0}-L \frac{d I}{d t}=R I
\end{gathered}
$$

separation of variables:

$$
\begin{aligned}
& \varepsilon_{0}-R I=L \frac{d I}{d t} \\
& \frac{d I}{\frac{1}{R} *\left(\varepsilon_{0}-R I\right)}=\frac{R}{L} d t \\
& \frac{1}{\frac{\varepsilon_{0}}{R}-I} d I=\frac{R}{L} d t
\end{aligned}
$$

integral on both sides:

$$
\begin{aligned}
& \ln \left(I-\frac{\varepsilon_{0}}{R}\right)=-\frac{R}{L} t+C \\
& I-\frac{\varepsilon_{0}}{R}=e^{-\frac{R}{L} t} e^{C}
\end{aligned}
$$

We calculate the integration constant. Assumption: for $t_{0}, I=0$, then:

$$
\begin{gathered}
e^{C}=-\frac{\varepsilon_{0}}{R} \\
I-\frac{\varepsilon_{0}}{R}=e^{-\frac{R}{L} t}\left(-\frac{\varepsilon_{0}}{R}\right) \\
I=\frac{\varepsilon_{0}}{R}\left(1-e^{-\frac{R}{L} t}\right)
\end{gathered}
$$

We introduce the the circuit's time constant $\tau$ :

$$
\tau=\frac{L}{R} \Rightarrow R=\frac{L}{\tau}
$$

The coil time constant is the time after which the current intensity will achieve the value $\left(1-\frac{1}{e}\right)$, of the set intensity equal to $I_{\max }=\frac{\varepsilon_{0}}{R}$ :

$$
I=\left(1-\frac{1}{e}\right) * \frac{\varepsilon_{0}}{R}
$$

The equation describing increase in the current on the coil in the RL circuit is obtained:

$$
I=\frac{\varepsilon_{0}}{R}\left(1-e^{-\frac{t}{\tau}}\right)
$$

Figure 5, shows the dependence on the current time in the coil. From Eq. (12), the exponential character of current growth in the coil can be inferred, in sections where the plot is smooth. Velocity of the growth of this current depends on the time constant $\tau$ of the coil, and on the expression $\varepsilon_{0} / \mathrm{R}$, present in this equation.

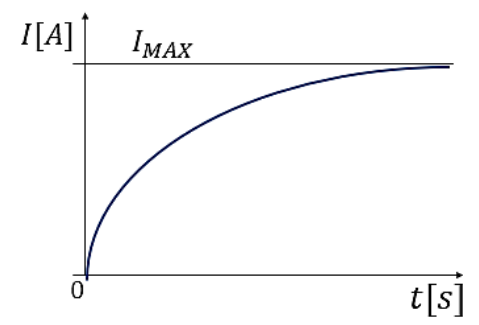

Fig. 5. Relationship I (t) in the coil

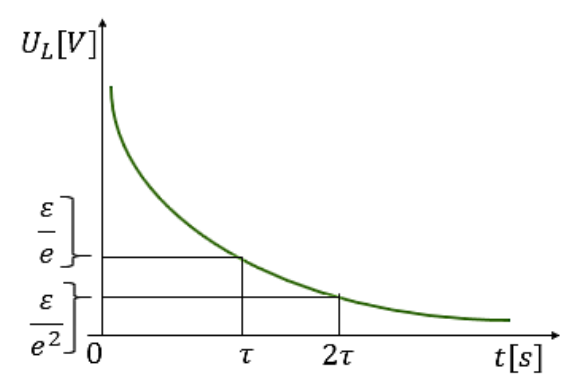

Fig. 6. Relationship UL (t) in the coil

Voltage UL of the inductance $\mathrm{L}$ is described by equation:

where: $U_{L}$ - voltage on the coil.

$$
\varepsilon_{0}=R I+\left|U_{L}\right|
$$

$$
\begin{gathered}
\left|U_{L}\right|=L \frac{d I}{d t} \\
\left|U_{L}\right|=\varepsilon_{0}-R \\
\left|U_{L}\right|=\varepsilon_{0}-R * \frac{\varepsilon_{0}}{R}\left(1-e^{-\frac{t}{\tau}}\right)
\end{gathered}
$$

The equation describing voltage decay on the coil is obtained:

$$
\left|U_{L}\right|=\varepsilon_{0} * e^{-\frac{t}{\tau}}
$$

Figure 6, shows the dependence of the coil voltage on the time in the RL circuit. Electromagnetic force in the injector coil $\mathrm{F}_{\mathrm{E}}[\mathrm{N}]$, is a result of the current flowing through the coil; the current changes over time depending on the induction electromotive force $\varepsilon_{0}[\mathrm{~V}]$. This is why analysing delays in injector needle travel on the basis of the waveform of the current flowing through the injector coil is possible, instead of considering all the forces from Eq. (21) [9]. Current flowing through the injector coil represents the sum of forces, which must be balanced by the current with the generated electrodynamic force. Injector opening time depends on:

- injection pressure - pressure "before" the injector;

- pressure in the tank, into which the dose is injected - pressure "after" the injector;

- density of the agent passing through;

- preset injection time (duration); 
- current and voltage supplying the injector coil.

When the injector needle closes the nozzle, pressure upstream of the injector acts against its opening. After an initial partial lifting of the needle, the flow of an agent starts and the force counteracting the further lifting of the needle diminishes. For this reason, the injector opening time $t_{o p}$ does not change linearly with the changed injection time, pressure, and gas density. The following factors influence the delay time of the injector needle lifting, which is shown in Fig. 7.

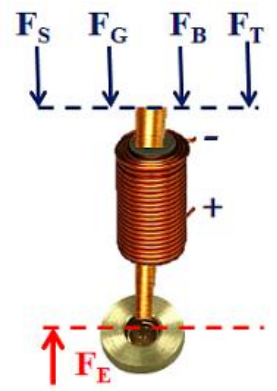

Fig. 7. Sum of forces affecting the needle [21]

$\mathrm{F}_{\mathrm{E}}$-electromagnetic force in the injector coil [N], $\mathrm{F}_{\mathrm{S}}$ - force of the injector spring $[\mathrm{N}]$,

$\mathrm{F}_{\mathrm{G}}$ - force generated by the injection pressure $[\mathrm{N}]$, $\mathrm{F}_{\mathrm{B}}$ - inertial force of the injector needle [N],

$\mathrm{F}_{\mathrm{T}}$ - friction force between the needle surfaces and the needle cylinder surface $[\mathrm{N}]$ :

$$
\mathrm{F}_{\mathrm{E}}=\mathrm{F}_{\mathrm{S}}+\mathrm{F}_{\mathrm{G}}+\mathrm{F}_{\mathrm{B}}+\mathrm{F}_{\mathrm{T}}[\mathrm{N}]
$$

\section{ACTUAL ELECTRIC CURRENT CURVES}

In the laboratory experiment, waveforms of the injection voltage and the current flowing through the injector coil were recorded for successive injections. Analysis of these parameters allows for determination of the delay time of the injector opening $t_{\mathrm{od}}$ and the closing time of the injector needle $t_{c l}$. Table 1 shows the waveforms of the current that were recorded for eight injection times, with the same values of the injection pressure. Together with the growing injection time $t_{i n j}$, a growth of the maximal current can be observed as well as the expansion of the current pulse, represented by the red line. The time of current growth increases after full lifting of the needle $t_{\text {od }}$ as well as the time of the current steady state $I_{\text {MAX }}=\frac{\varepsilon_{0}}{R}$. A growing scope of space below the line denoting the current, from the successive plots from Table 1 , is assigned to the growing doses from Figure 8, for the same injection (duration) times. At short injection times of up to $2 \mathrm{~ms}$, the fuel flow is obtained due to the delay in the needle closing. Up to the injection duration of $3.5 \mathrm{~ms}$, the current does not achieve its maximal value (preset value). It can be observed that the size of the fuel dose can be determined due to the observation of the current fluctuation in the injector coil. Figure 9 illustrates changes in voltage and intensity of current flowing through the injector coil during generation of a gas dose. The graph was accomplished at the following injection parameters:

- injection time $t_{\text {inj }}=9 \mathrm{~ms}$;

- pressure in the container, where the dose was injected $\mathrm{p}_{\mathrm{c}}=1.8$ bar;

- injection pressure $p_{\text {inj }}=2.8$ bar;

- supply voltage: $U_{c}=12 \mathrm{~V}$

Tab.1. Current waveforms $\mathrm{t}_{\mathrm{ini}}=17 \mathrm{~ms} \div \mathrm{t}_{\mathrm{ini}}=9 \mathrm{~ms}$.
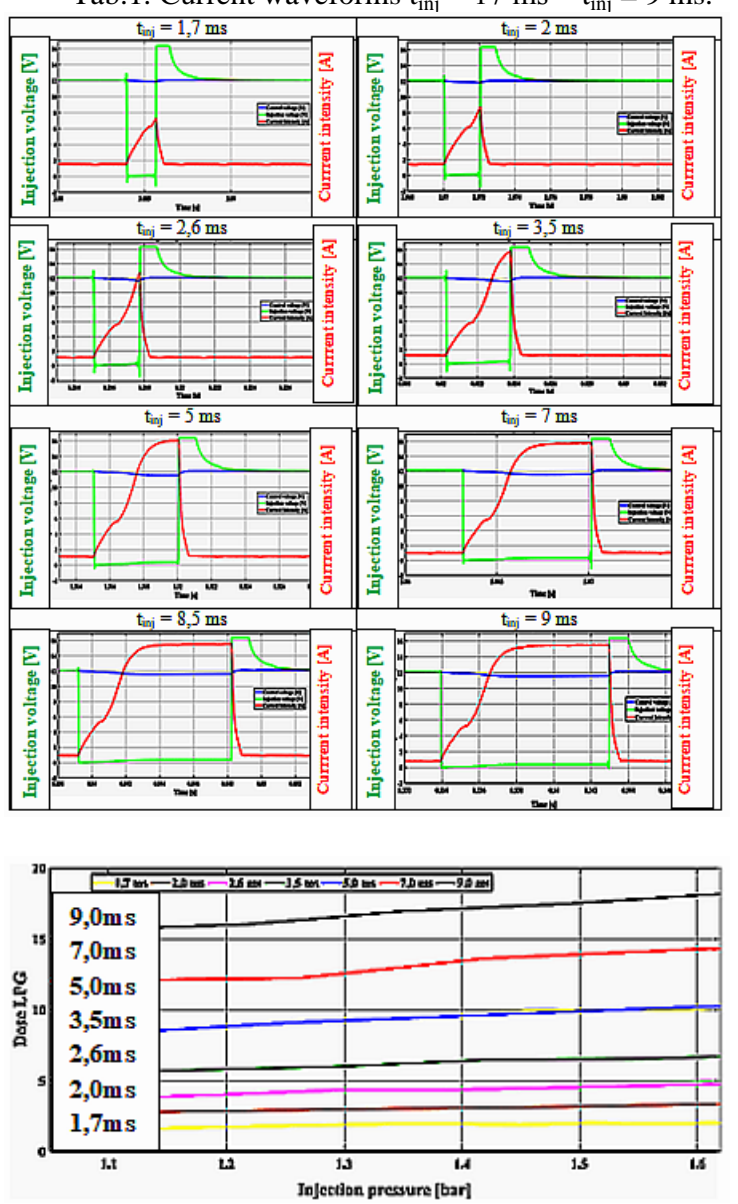

Fig. 8. LPG doses in relation to the injection pressure, at different injection times (duration)

The starting point of a current pulse is the $0.015 \mathrm{~s}$ point. Current intensity grows exponentially, at the closed injector needle, up to the $\sim 0,017 \mathrm{~s}$ point. The current generates the growing magnetic flux and the resulting electrodynamic force does not exceed mechanical forces counteracting the needle lifting. The change in the magnetic flux causes creation of the self-inductance stream (of the opposite sign). At the 0.017 point, overcoming of the needle resistance forces by the resultant stream takes place, and within 150-250 microseconds the needle opens the flow through the injector nozzle. At the point of the needle opening, due to the balancing the needle resistance forces and the electrodynamic force, the current intensity curve is bent $\left(\frac{d I}{d t} 0\right)$. Subsequently, the current grows expotentially, at the lifted needle, in accordance with the theoretical curve in the RL circuit (Fig. 5), striving to reach the fixed value $\frac{\varepsilon_{0}}{R}$. As long as the 
current grows, the magnetic flux increases and its change generates the stream of self-inductance of opposite sign. After the current achieves the fixed value, the magnetic flux has a constant value, hence the stream of self-inductance in the coil decays, Eq. (2). At the $0.024 \mathrm{~s}$ point, the current pulse ends for $\mathrm{t}_{\text {inj }}=9 \mathrm{~ms}$. As a result of disconnecting the circuit, high voltage is induced in the coil, whose value is greater than that of the supply voltage (in the voltage plot the horizontal line, due to removing of the greater values by the measurement card). After the point leap, the voltage decreases exponentially in accordance with the theoretical curve in the RL circuit (Fig. 6).

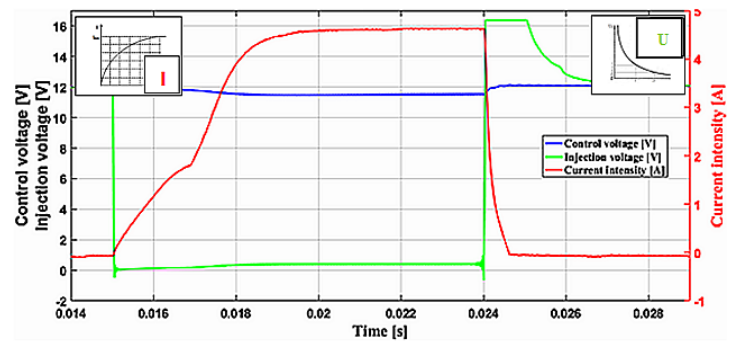

Fig. 9. Waveform of the injection current at $t_{i n j}=9$ $\mathrm{ms}$ and $\mathrm{p}_{\mathrm{inj}}=2.8 \mathrm{bar}$

Voltage decay in the coil takes place in accordance with Eq. (2):

$$
\begin{gathered}
\varepsilon_{S I}=-\frac{d \varphi}{d t}=-L \frac{d I}{d t} \\
\left|U_{L}\right|=\varepsilon_{0} * e^{-\frac{R}{L} t}
\end{gathered}
$$

Observing the current decay, we can notice a precisely defined point, where the needle closes the injector nozzle - the flow is terminated. This is a point, at which this plot ceases to be smooth for 100 microseconds $(0.0257 \mathrm{~s})$. To explain the fact that this denotes the point of the needle closing the nozzle, a phenomenon of change in the injector core inductance was used, which results from the needle's movement inside of it. If we go back to the $0.024 \mathrm{~s}$ point, here begins the exponential drop in the voltage at the coil, with the simultaneous change in the core inductance. At the $t=0.0257 \mathrm{~s}$ point, the needle touches the nozzle, inductance achieves the constant value, ensuing the point of the plot's sudden drop, resulting from Eq. (2) and (20), precisely defining the nozzle's closure (Fig. 10). Further on, the voltage of the coil decays at the constant inductance and obstructed fuel flow. The shorter the injection duration, the greater the difference between the preset and the real injection times. For each injection time, however, as an effect of the needle operation delay, the shifted injection phase (delayed) is obtained. The greater the ratio of inductance to the coil resistance (L/R), the longer the current increase, and delays in injector operation and phase shifts - greater.

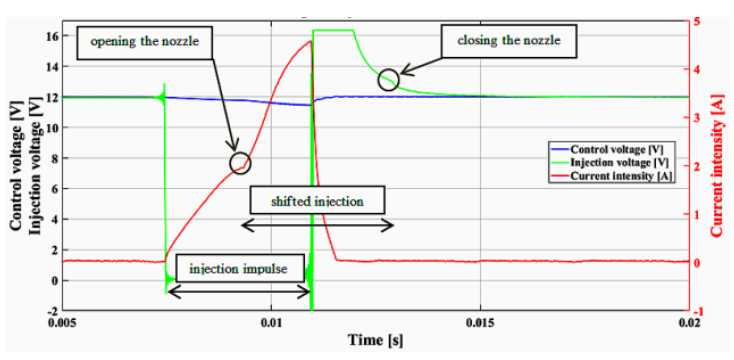

Fig. 10. Changes in the current during $5 \mathrm{~ms}$ fuel injection.

\section{SUMMARY}

Observation of the current growth in the injector needle allows for determination of the injector needle travel during its lifting, whereas observation of the voltage decay enables precise determining of the needle closure point. Instead of considering all the forces acting on the needle (21), it is sufficient to analyse the current-voltage waveforms in the course of generating the flow. The current waveform reflects the sum of all the resistance, which must be balanced by the generated electrodynamic force resulting from the current. The closing point of the injector needle was determined due to the analysis of relationships regarding the RL circuit (20) and the obtained characteristics. The actual time of the injector opening is a sum of: the operation delay, needle lifting, steady state and needle closure delay. Transient periods and their proportion to the steady state decide about the total volume of the gas dose. The article illustrates how the parameters of the current measured during injector's operation reflect the specific fuel dose that will be obtained as a result of the flow through the injector nozzle. The current enables determination of the actual needle position. The time of the real fuel flow and the injection phase position can be determined with the microsecond resolution, observing the resultant of the coil current and voltage plot. The inductance of the injector core is a constant quantity but as a result of the needle movement and change in permeability, the core inductance changes depending on the needle position. These quantities, closely related to the current flowing the coil, are described with the differential resulting from the Kirchhoff's law, due to which the occurring changes can be substantiated. The accurate control of the flow allows for the precise controlling of the injector in actual time, due to application of fast analogue-digital converters and adequate algorithms. In the control, delays in operation of the pulse injector and shifts in the flow phase are taken into consideration. Varying flow parameters and resistance of the needle movement are overcome by the magnetic flux resulting from the current flowing through the coil. This is why the fuel injection can be controlled solely on the basis of the current parameters, hence they model changes in the flow parameters. 


\section{REFERENCES}

1. Perryman L, Baker NP, Martin SJ, Martin AP. Drive circuit for injector arrangement and diagnostic method. Delphi Technologies Holding. 23 June 2011. Espacenet.

2. Wierzbicki S, Śmieja M, Grzeszczyk R. Zintegrowane sterowanie stanowiskiem badawczym silników o ZS w środowisku fast prototyping. Combustion Engines. 2013; 3(154): 536-541.

3. Czarnigowski J. Theoretical and empirical study modeling pulse gas injector. Copyright by Lublin University of Technology. 2012.

4. Jukl M, Dostál P, Čupera J. Analysis of engine parameters at using diesel - LPG and diesel CNG mixture in compression - ignition engine. Acta Universitatis Agriculturae et Silviculturae Mendelianae Brunensis, 2014. 62(1):125-130

5. Czarnigowski J. Effect of calibration method on gas flow through pulse gas injector: Simulation tests. Combustion Engines, 2013; 154(3): 383-392.

6. Czarnigowski J. The model of pulse injector opening lag time. Combustion Engines. 2013; 154(3): 393398.

7. Jiang $\mathrm{C}, \mathrm{Xu} \mathrm{H}$, Srivastava $\mathrm{D}$, Ma $\mathrm{X}$, Dearn $\mathrm{K}$, Cracknell R, Krueger-Venus J. Effect of fuel injector deposit on spray characteristics, gaseous emissions and particulate matter in a gasoline direct injection engine. Applied Energy. 2017:203:390-402; http://dx.doi.org/10.1016/j.apenergy

8. Cammalleri M, Pipitone E, Beccari S, Genchi G. A mathematical model for the prediction of the injected mass diagram of a S.I. engine gas injector. Journal of Mechanical Science and Technology 2013;27(11): 253-365.http://dx.doi.org10.1007/s12206-013-0848-6

9. Borawski A. Simulation studies of LPG injector used in 4th generation Installations. Combustion Engines. 2015; 160(1): 49-55.

10. Krogerus TR, Huhtala KJ. Diagnostics and identification of injection duration of common rail diesel injectors. Open Engineering. 2018, 8(1):1-6. http://dx.doi.org/10.1515/eng-2018-0001

11. Farooqi QR, Snyder B, Anwar S. Real time monitoring of diesel engine injector waveforms for accurate fuel metering and control. Journal of Control Science and Engineering. 2013;2013:5. http://dx.doi.org/10.1155/2013/973141

12. Czimmek P, Wright D. A method of using inductance for determining the position of an armature in an electromagnetic solenoid. 1999-07-13. US6657847B1 patent USA, base ESPACENET.

13. Szpica D. Comparative analysis of the characteristics of a low-pressure gas-phase injector. Flow Measurement and Instrumentation. 2017; 58:74-86.

14. Armas O, Mata C, Martinez-Martinez S. Effect of diesel injection parameters on instantaneous fuel delivery using a solenoid-operated injector with different fuels. Revista Facultad De IngenieriaUniversidad De Antioquia. 2012; 64:9-21.

15. Warczek J. The application of PCA to develop a vibration pattern of the LPG injector. Conference materials - XVII International Technical Systems Degradation Conference. 2018.

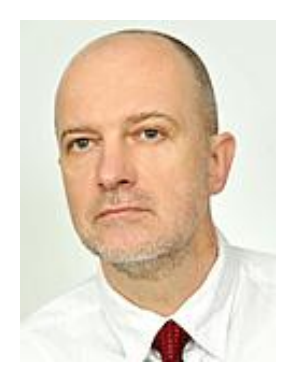

Krzysztof WIĘCLAWSKI

received the title of MSc. in Warsaw University of Technology, Warsaw. Now he is an employee of Warsaw University of Technology, and runs his own company. His current research interests include control and fault diagnosis.

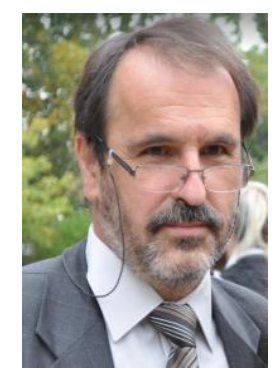

Jędrzej MĄCZAK, PhD, DSc Professor at the Institute of Vehicles of the Warsaw University of Technology. Scientific interests: distributed diagnostic systems, machine diagnostics, mathematical modelling of power units and methods of analysis of vibroacoustic signals.

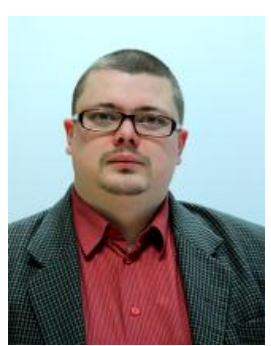

Doc. Eng. Krzysztof

SZCZUROWSKI, $\mathrm{PhD}$ is a postdoctoral manager at Integrated Laboratory of Mechatronics System of Vehicles and Construction Machinery of Warsaw University of Technology. His scientific interests include computational mechanics, sound and vibration and mechatronics. 